\title{
How \\ Organizational \\ Abusive \\ Supervision \\ Hypocrisy \\ Cultivates \\ Resilience \\ impedes it: \\ Whereas \\ Supervisor Resource Building Approach
}

\section{Anwar ul Haq', Syed Tahir Rizvi²}

${ }^{1} \mathrm{PhD}$ Scholar International Islamic University Islamabad

${ }^{2}$ Director Quality Enhancement Cell, International Islamic University Islamabad

\section{A B S T R A C T}

This study adds to the research of business ethics by exploring how organizational hypocrisy affects abusive supervision positively, through the mediating role of cynicism of supervisors and when supervisor resilience can temper down abusive supervision. This is the first study to use frustration aggression theory to explain the studied mechanism and further contributes to the literature of theory by proposing that frustration may lead to broadening of scope of cognitive processes thereby developing new positive goals. Using a quantitative design multisource data were collected in three waves through survey method. Results of the data analysis confirmed the entire hypotheses of the study in proposed directions. This study highlights a dangerous pathway that may generate vicious cycles of negativity and undermine long term viability of organizations but at the same time gives a unique solution to organizations to decrease the effects of hypocritical policies. The study can have far reaching organizational and social implications. Organizations can benefit from this research by reviewing their management philosophies and HR practitioners can focus on developing pools of resilient employees to make organizations and society green. At the end limitations of the study are discussed and future research directions are suggested.

Key Words: Resilience, Organizational hypocrisy, Abusive supervision, Organizational cynicism.

\section{INTRODUCTION}

In the modern business world characterised by hyper-competition, taking decisions that are profitable for the organization, satisfy the internal external stake holders and abide by the ethical values of the society is becoming increasingly difficult. Talking about ethical pressures, public opinion about business world's ethics was not 
found good in last thirty years of the last millennium and scholars of the field were not optimistic about any changes in it in the millennium ahead (e.g. Carroll, 2000; KishGephart, Harrison, \& Treviño, 2010; Margolis \& Walsh, 2003). In 1960s and 70s organizations often tried to appear ethical to the society yet failed to keep their words when it came to actions. Such ethical issues and inability to comply with ideals had lead many organizations to virtual collapse in 1980s (De Cremer, Tenbrunsel, \& van Dijke, 2010; Fine \& Shulman, 2009g).

Employee behaviours that harm or intend to harm the organization or its stakeholders have been found to be a significant problem for $95 \%$ of all organizations resulting in estimated in annual losses worth hundreds of billions of dollars (Wurthmann, 2020). No doubt this is a glaring indication of crises in the business world brewing behind organizational efforts for seeking legitimacy, far more bigger and complex, than what has been apprehended and visible to society in the shape of few high-profile scandals like, Enron, Tyco, WorldCom etc. (Pandey, Chandwani, \& Navare, 2018; Zona, Minoja, \& Coda, 2013) , Apple, Nike, McDonald's and Starbucks (D. Sharma, 2018).

To understand the emergence of various unethical behaviours at workplace, there is a growing consensus among researchers that organizations are no more innocent bystanders and organizational variables must be accounted for besides personal characteristics of organizational members towards better understanding of organizational misbehaviours. Organizational scholars have identified a number of important contextual factors that drive unethical organizational behaviour, most importantly including ethical climate (Kuenzi, Mayer, \& Greenbaum, 2019; Mayer, Kuenzi, Greenbaum, Bardes, \& Salvador, 2009; Walumbwa, Hartnell, \& Misati, 2017; Wimbush \& Shepard, 1994), and perceived ethical values (Wimbush \& Dalton, 1997). It has been observed that perceived ethical values are related to unethical decision-making by managers (Biron, 2010). However, though research in behavioural ethics is gradually gaining momentum among business ethics scholars (de Colle \& Freeman, 2020) practical workplace application of the insights generated by this growing scholarship has been found limited.

To address the issue of unethical behaviours at workplace, business ethics researchers have been moving towards new conceptual approaches such as Eastern 
philosophy (Koehn, 1999; Mulla \& Krishnan, 2014), behavioural ethics (Cropanzano \& Stein, 2009), wisdom (Zacher, Pearce, Rooney, \& McKenna, 2014). Most recent approach adopted by some eminent Muslim scholars of the field is to introduce Islamic Work Ethics as an ultimate solution for bringing an inner change that they have empirically found not only to have been preventing people from adopting unethical behaviours, even when faced with abusive behaviours at workplace, by virtue of their faith in Allah (Javed, Fatima, Yasin, Jahanzeb, \& Rawwas, 2019) but it practically creates in them helping attitudes towards others at workplace (De Clercq, Rahman, \& Haq, 2019). But IWE is considered to be by definition religiously biased and as these studies were carried out in Islamic Republic of Pakistan, with mostly Muslim citizenship, the results of the studies need further authentication in different religious contexts before their vide acceptability as practically useful in adverse workplace contexts.

Pending the streaming of this line of research, however, the purpose of this study is to explore how supervisor resilience (which closely resembles IWE but do not have a religious shade like it) can temper down abusive supervision when it may emerge under the influence of frustrating organizational hypocritical policies. The second goal of this study based on positive psychology literature, is to extend the boundaries of Frustration Aggression Displacement theory (Dollard, Miller, Doob, Mowrer, \& Sears, 1939) and to suggest that "it is really the man who is the measure of all things"; internally resilient, man can change environmental negativity to positivity. To explore these goals, the study model has been developed by identifying linkages between three most toxic variables capable of generating pathological behaviours in routine day to day work and then we conceptualize an inverse moderating effect of supervisor resilience on this pathway based on initial literature review.

Scholars have viewed organizational power and sectional interests as characterized by ambiguities and messiness resulting in organizational disorder and obstruction of organizational rationality (Alvesson, 2020). Yang, Manika, and Athanasopoulou (2019), observe that "organisational hypocrisy can be damaging for business and society as it may intensify the gaps between commitments and resources, undermine reforms, or fail to protect society from externalities". Similarly, it has been 
found to undermine positive attitudes towards a firm held by consumers (Ioannou, Kassinis, \& Papagiannakis, 2018; Wagner, Lutz, \& Weitz, 2009) or a brand (Sweetin, Knowles, Summey, \& McQueen, 2013). Such facts like false or contradictory claims and practices, false promotions, bait marketing, counterfeit products, mislabelling, and privacy infringement, offer a huge room for potential corporate hypocrisy to be perceived unethical by consumers and employees alike (Goswami \& Ha-Brookshire, 2018) so much so that people may perceive an organization as unethical even if it falls short of their selfproclaimed standards of social responsibility(Wagner, Korschun, \& Troebs, 2019). In such a situation organizational actions become morally dubious and prone to creation of confusion (Brunsson, 2007). In addition, it has been found that ethical climate effects behaviours of employees and unethical practices by the organizations may lead the employees to harbour turnover intentions (Mayer, Kuenzi, \& Greenbaum, 2010; Mulki, Jaramillo, \& Locander, 2008; Simha \& Cullen, 2012; Yurtkoru, Ensari, \& ErdilekKarabay, 2018).

It has been observed that having values and consistent adherence to these values play a key role in the interpretation and implementation of practices (Jacqueminet, 2020). Complex decision-making structures of the organizations and their effort to meet with discordant stakeholders' demands, makes it difficult for them to align their claims and goals with actions taken by its agents. This results in appraisals of inconsistencies between motives, actions and values (Arthur G Bedeian, 2007) which may be perceived as a lack of integrity and open the doors to organizational cynicism (Pfrombeck, Doden, Grote, \& Feierabend, 2020). Organizational cynicism is a negative attitude of employees towards the organization. As conceptualized by Dean and colleagues, it comprising cognitive, affective, and behavioural components. Such cynical employees believe that their organization lacks integrity, they experience negative emotional state towards their organization, and exhibit propensity to critical and disparaging behaviours (Dean Jr, Brandes, \& Dharwadkar, 1998).The negative consequences that have been documented by numerous studies include for example, on employees' job performance (Kim, Jung, Noh, \& Kang, 2019), work alienation (Li \& Chen, 2018) counter workplace behaviours (CWB) (Li \& Chen, 2018; Tong, Chong, Chen, Johnson, \& Ren, 2020), turnover 
intentions (Rice, Taylor, \& Forrester, 2020) and deviant workplace behaviour (Evans, Goodman, \& Davis, 2010; Moghaddam \& Mahmoudi, 2018). Aversive leader's behave in way to create social isolation for their targets which generates feelings of estrangement in employees and may deplete employees' psychological resources by consuming time, energy and efforts needed to move back toward to the inner circles of leader "guanxi" (Zhao, Chen, Glambek, \& Einarsen, 2019).

Based on such findings it is conjectured that supervisor level employees may also experience negative emotions like stress in the form of anguish and intentions to sabotage (K1lıçoğlu, K1lıçoğlu, \& Karadağ, 2017; Naus, 2007) the organization as a result of organizational hypocritical policies and practices. Thus, organizational hypocrisy can have a pathological effect on employees giving birth to cynicism in them (and here we take into account the supervisor level employees) the aftermath of which could be abusive supervision (Lam, Walter, \& Huang, 2017).

Secondly, however, abusive supervision is not an absolute devil that cannot be avoided (Gonzalez-Morales, Kernan, Becker, \& Eisenberger, 2018; Javed et al., 2019). Besides the existence of negativities in corporate world, positive streams also flow in working of organizations. It has been studied that people may reciprocate negativity with negativity yet individuals may respond positively to the negative environmental cues; people possess pathological as well as growth potentials (Vansteenkiste \& Ryan, 2013). They can be depleted self-centred, irresponsible and reciprocate to contextual factors in aggressive manner but they can be vital, open, curious and caring, and depict potentials for growth and flourishing. In the light of Mackey, Frieder, Brees, and Martinko (2017) advice of studying abusive supervision under the framework of different theories, the objective of this study is to explore the topic of antecedents of abusive supervision three dimensionally (dynamics of interaction of negative environmental factors, negative personal states and positive personal states) under the umbrella of frustration aggression displacement theory of Dollard et al. (1939), further developed by N. E. Miller (1941) supported by broaden and build theory (B. L. Fredrickson, 2001) to have a better understanding of the of the mechanism through which organizational hypocrisy impacts abusive supervision and to understand what personal factors might forestall this process. 
As such, the graphical presentation of the model of study conceptualized for empirical testing is outlined as under:

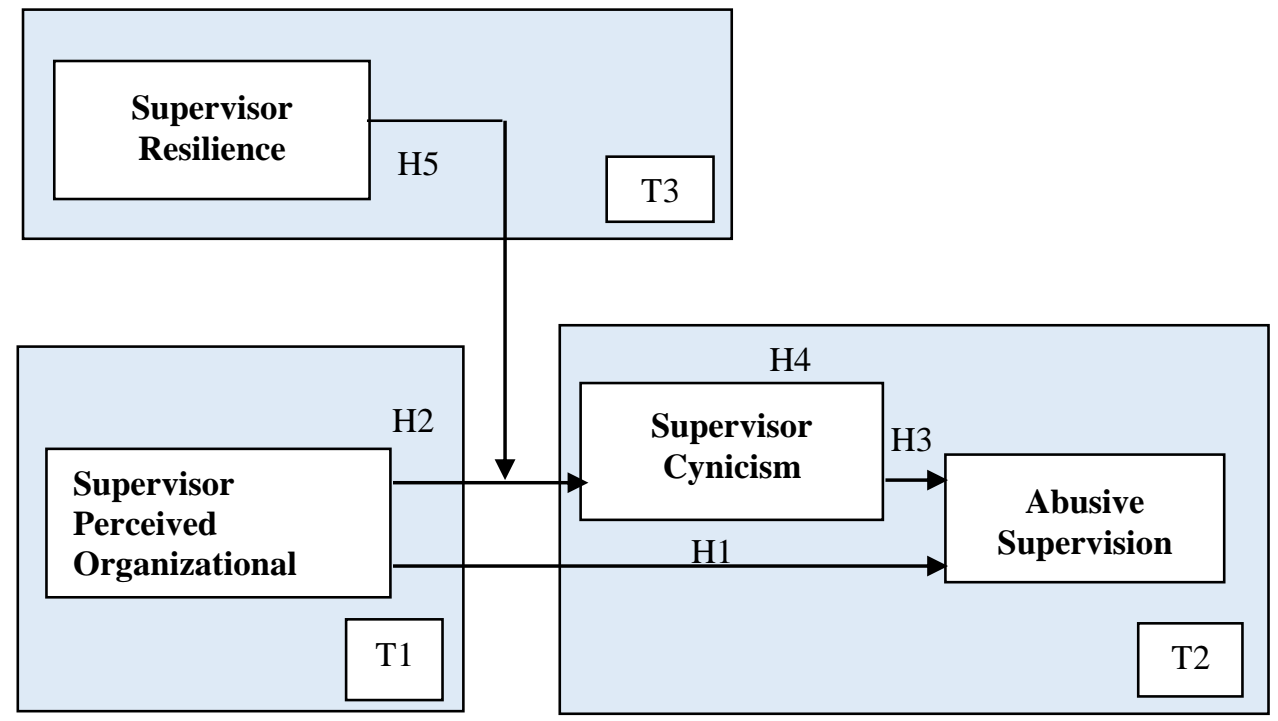

Figure 1. Graphical presentation of the studied model

\section{LITERATURE REVIEW}

\subsection{Theoretical Underpinnings of Conceptualized Relations}

Frustration-aggression-displacement theory posits that when the goals are frustrated, people become aggressive and scapegoat something other than the source of frustrations to regain a sense of relief from their feelings of frustration.Allen and Anderson (2017) have observed that "while the criteria for events to qualify as frustrating are quite well defined, the types or the sources of frustrations are extremely diverse". E.g events that cause reduction in self-efficacy of the individual (Bandura, 1977) or his effectance (White, 1959) are also characterized as frustration. Lazarus (1991) has observed that the blockage of the goal which is personally important to subject results in negative affect. As people want to retain moral self-image (Jordan, Mullen, \& Murnighan, 2011), they experience a state of cynicism towards the organizational practices of hypocrisy when they find themselves a part of an organization that lacks consistency in decisions effecting people and society at large adversely. This inconsistency is more pronounced for supervisors compared to supervisees as they find it 
more difficult to exercise control on subordinates and implement inconsistent organizational decisions. Thus, following the norm of negative reciprocity (Gouldner, 1960), such supervisors experience a felt obligation of not to care about organizational welfare and goals (Eisenberger, Huntington, Hutchison, \& Sowa, 1986) and displace their aggression actually in the form of abusive supervision.

However, it has been noted that such episodes of abusive supervision may happen more frequently especially when a supervisor lacks the capacity to inhibit, override, or refrain from impulsive behaviours effectively (Wang, Sinclair, \& Deese, 2010). Keeping individual differences in view, employees' experiences of distress causing events can result in positive conscious responses based on broadening of the scope of thinking and positive emotions. The broaden-and-build theory of Fredrickson $(1998,2004$; 2001) posits that positive emotions help broaden the scope of attention and build repertoires of thought and action tendencies in mind (Fredrickson \& Branigan, 2005), which in turn build resilience to buffer against future emotional setbacks (Brown, Sokal, \& Friedman, 2013). In addition, Fredrickson and Losada (2005) proposed that an individual's degree of growth could be predicted by that person's ratio of positive to negative emotions over time. Individuals thrive at work (Thriving at work refers to a positive psychological state characterized by a joint sense of vitality and learning) when they have ability to "bounce back and attain success"(Kleine, Rudolph, \& Zacher, 2019)

\subsection{Abusive Supervision}

Just like organizational hypocrisy, abusive supervision has also been found to cost heavily to the organization. Abusive supervision, is sustained display of verbal or non-verbal hostility toward followers as defined by Tepper (2000). Abusive supervision is considered as an intensive form of such undesirable leadership, that includes a continuum of behaviours like giving degrading looks, threatening, yelling, giving silent treatment, assigning disadvantageous work assignments, not assigning any task, spreading rumours about subordinates, and/or belittling at its mild end and human rights violations at its extreme end (Lam et al., 2017; Tepper, 2000; Tepper, Moss, \& Duffy, 2011). Indeed, usage of such language which is demeaning can have negative efects on targets' attitudes, selfworth, and behaviors (Park et al., 2019). Employees who experience 
such supervisor behaviours may suffer from lowered health and wellbeing and suffer from high job and life dissatisfaction, problem drinking, workplace withdrawal, turnover intentions, psychological distress, absenteeism, citizenship behaviour and workplace deviance (Ashforth, 1997; Bamberger \& Bacharach, 2006; Kluemper et al., 2019; Mitchell \& Ambrose, 2007; E. Xu et al., 2020; S. Xu et al., 2018; Zellars, Tepper, \& Duffy, 2002) . It has been estimated to cause a loss of $\$ 24$ billion annually on account of employee turnover, decreased productivity and escalated health and insurance compensation claims (Tepper, Duffy, Henle, \& Lambert, 2006; S. Xu et al., 2018). Sharma found that the magnitude of effect of mistreatment of employees by the supervisors, co-workers, and outsiders is strongest in case of supervisor behaviours compared to mistreatment by co-workers and outsiders (P. N. Sharma, 2018). No wonder the phenomenon of abusive supervision has been described as the "dark side of organisational behaviour" (Griffin, O'Leary-Kelly, \& Pritchard, 2004; Park et al., 2019).

Given the importance of the subject, a largely increasing number of empirical studies have been devoted to this important concept (Tepper, Simon, \& Park, 2017) since the seminal work of Tepper (2000) on abusive supervision. However, attention of the researchers to finding the causes of this behaviour has turned in recently (Zhang \& Bednall, 2016). P. N. Sharma (2018), has observed that researchers should "consider the juncture of the different forms of leader workplace aggression with organizational characteristics". This research is therefore timely in the light of concerns shown about dark side of leaders and its increasing effects on corporate turmoil (Braun, Kark, \& Wisse, 2018) especially so in Pakistani context where no such study has hitherto been carried out on the subject to the best of knowledge of the researchers.

\subsection{Effect of Organizational Hypocrisy on Abusive Supervision}

Among various categories of the antecedents of abusive supervision studied hitherto, organizational characteristics have been found to have profound effect on employees' emotions, performance and behaviour (Aslam, Muqadas, Imran, \& Rahman, 2018). For example, employees disregard organizational norms and values and indulge in negative deviant behaviours when organization's norms, attitudes and social values are not centred to a specific organizational culture based on important ethical core values 
(Appelbaum, Iaconi, \& Matousek, 2007), employees do not perceive organization meting out justice to its employees (O'Connor \& Crowley-Henry, 2019). It has also been found that perceived low behavioural integrity of the employer (i.e. perceived inconsistency between the employer's values and behaviour) undermine employee commitment to perceived organizational ethical values (Molina, 2018; Peng \& Wei, 2018) and results in failure to meet the behavioural standards that follow from these values. This perception of low organizational behaviour integrity (as depicted by organizational hypocrisy) can lead to interpersonal deviance through negative reciprocity (Biron, 2010).

Hypocrisy is "failing to practice what one preaches, reflecting behavioural inconsistency, which stems from perceptions of disingenuousness" (Hale Jr \& Pillow, 2015). Arthur G Bedeian, Armenakis, and Curran (1981) have classified organizational decision-making practices as organizational climatic factors. As such organizational hypocrisy is categorized as an organizational climatic factor in this study. Organizational hypocrisy is described as disjuncture or "decoupling" of the stated values, plans, and operational practices within organizations (Argyris \& Schon, 1974; Bromley \& Powell, 2012; Brunsson, 1993; Fernando \& Gross, 2006; Huzzard \& Östergren, 2002; Jacqueminet, 2020; 2000; Meyer \& Rowan, 1977; Posner \& Kouzes, 1993). Furthermore, Brunsson (1989) postulates that inconsistencies in the outputs or products reflect inconsistencies in the environment. Indeed, organizations can employ inconsistencies within their talk, decisions, or products in order to win legitimacy and support from the environment(Yang et al., 2019). But acting hypocritically, organizations close the gap between their image and their daily practices by weakening their credibility (Christensen, Morsing, \& Thyssen, 2011). Wagner et al. (2019), however, defining corporate hypocrisy as "the belief that a firm claims to be something that it is not" opines that the existence of a lot of different definitions of the construct suggest that current understanding of the concept is still underscored and needs to be improvised.

It has been found that supervisors who have experienced mistreatment are prone to hostility (Tepper et al., 2006) and when employees have unfavourable perceptions of their situation at work, they are more likely to violate organizational norms and behave abusively (Robinson \& Bennett, 1995). According to frustration aggression displacement 
theory however, they will, express their aggression against targets other than the organization (i.e the provoking agent) out of fear that doing so may evoke further mistreatment by the organization (Tepper et al., 2006). In other words, the authors have observed abusive supervision as displaced aggression against targets that are "safe" to be hostile with, in this case the direct reports of supervisors. The study conducted by Hoobler and Brass (2006) provides another support for a displaced aggression explanation for the emergence of phenomena of abusive supervision in the organizations. They have noted that those supervisors were more abusive towards their subordinates who experienced psychological contract breach. It is therefore hypothesized that:

$\mathbf{H}_{1}$ : Supervisor perception of organizational hypocrisy is positively related to abusive supervision.

\subsection{Direct Effect and Mediating Role of Supervisor Cynicism}

Study of the extent research shows that organizations need employees with favourable work attitudes and emotions to thrive. It has been found that in fact the reverse prevails; many organizations suffer from bad health and experience dwindling viability due to unfavourable attitudes and emotions of its employees. One such variable that has not been studied as mediator and direct antecedent of abusive supervision is organizational cynicism. Dean Jr et al. (1998) have conceptualized organizational cynicism as an attitude comprised of three primary components: 1) a belief that the organization lacks integrity; 2) a negative affect toward the organization; and 3) a tendency to disparage organization and criticize it. Previously negative feelings of supervisors have been found to mediate relationship of adverse experience of a supervisor (like interpersonal deviance) and abusive supervision (Eissa, Lester, \& Gupta, 2019) and it has been found that organizational cynicism mediates the relationship between breach of psychological contract and job involvement (Nadim, Fatima, Aroos, \& Hafeez, 2019). Kanter and Mirvis (1989), found that organizational cynicism prevailed in $43 \%$ of American workers whereas Reichers, Wanous, and Austin (1997), observed 48\% of the participants of their study as high on organizational cynicism. In addition, it has been viewed that organizational cynicism has only increased in recent years (Archimi, Reynaud, Yasin, \& Bhatti, 2018; Bommer, Rich, \& Rubin, 2005) just like organizational 
hypocrisy.

The core belief of an organizational cynic is that that organization toes only selfinterests throwing to winds principles of fairness, honesty, and sincerity leading to actions based on hidden motives and deception (Abraham, 2000). Emergence of such an attitude characterised by aggressive emotions is explainable in terms of frustration aggression theory. At the first place, people have different beliefs about their social environment. For example, some people may view the world full of selfless, caring and loving people but others view the society rife with injustice, exploitation, competition and organizations as untrustworthy (Leung, Ip, \& Leung, 2010). If the working conditions are adverse, the spontaneous response of second type of employees would naturally be of mistrust and disgust. Numerous scientific studies have demonstrated the existence of negative attitudes originating from adverse working conditions (Naus, 2007). When supervisors perceive organization as hypocritical, they may lose the base of "collective activity, mutual assistance, and joint accountability; and binds individuals to one another in organizations" (Kılıçoğlu et al., 2017). Workplace experiences have been found to predict organizational cynicism as an attitudinal state (F. Naus, A. van Iterson, \& R. A. Roe, 2007; Reichers et al., 1997).

In the literature it is suggested that cynicism has to be understood as a form of self-defence, to cope with and make sense out of puzzling or disappointing events (Reichers et al., 1997) that could be organizational hypocrisy. Studies on organizations demonstrated that organizational cynicism was common in organizations where organizational hypocrisy prevailed (Kılıçoğlu, Yılmaz, \& Karadağ, 2014; Naus, 2007; Simons, 2002). Organizational cynicism is associated with employees' disappointment in, and frustration with, the organization, and undermines their will to achieve performance targets (Kim et al., 2019)

$\mathrm{H}_{2}$ : Supervisor perception of organizational hypocrisy is positively related to supervisor cynicism.

Organizational cynicism has been observed to be negatively related to employee commitment and job performance (Andersson, 1996). The way people believe and think about others and the work environment around them in turn determines their behaviours 
in social settings (Deng, Guan, Bond, Zhang, \& Hu, 2011; Leung et al., 2002). Leadership researchers have observed that leaders with positive beliefs tend to hold more sanguine expectations from subordinates and this attitude is positively related to employee aspirations and performance (Eden, 2003; Sager, 2008). Whereas leaders with cynical beliefs about the world around them remain sceptic of the intensions of others which affect the way how they interact with and relate to their followers (O. A. Byza, Schuh, Dörr, Spörrle, \& Maier, 2017). More specifically research studies have shown that leaders with cynical views are prone to behave in the manner that undermines the motivation and performance of their followers (O. Byza, 2018). Untrustworthiness of organizations may add fuel to the fire.

We argue that credibility of the organizational policies and practices is basic need of the supervisors like any other employees. They would perceive it as a support if they have to implement organizational decisions through subordinates to achieve the goals assigned to them. Similarly, irrational decisions may also be resisted by the subordinates and the inconsistency between internal structures and external environment of the organization may also be perceived as unfair which may be personally important to the supervisors. Hence, perceptions of organizational hypocrisy create the conditions of mistrust between the supervisor and the organization on one hand and him and subordinates on the other hand. This leads to thwarting of psychological needs of competence (as it may be difficult to execute hypocritical decisions of the organization), relatedness (as it may strain the relationships with the subordinates who would challenge the irrational decisions), and autonomy (as the hypocritical decisions are taken by the management without the involvement of supervisors). This may result in frustration of goals (Bandura, 1977; Ryan \& Deci, 2000a, 2000b) and negative affect (Lazarus, 1991) coupled with intensions to sabotage the organization. But through a simple reasoning discussed above, the intentions to sabotage the organisation may be displaced by nonphysical aggression towards the employees as explained while development of the first hypothesis. Hence it is hypothesized that:

$\mathbf{H}_{3}$ : Supervisor cynicism is positively related to abusive supervision.

Organizational mistreatment of its employees has also been found to be related 
with increased emotional exhaustion (Johnson \& O'Leary-Kelly, 2003) and to have a spill-over effect on supervisor subordinate relationship (Neves, 2012). Studies have found that strong negative affect mediates the perceptions of organizational mistreatments and supervisors' hostility towards their subordinates.Tepper et al. (2006) e.g had noted that supervisor depression mediated the relationship between supervisor experience of procedural injustice and abusive supervision and similarly Eissa and Lester (2017) found that supervisor frustration mediates the relationship between supervisor work overload and abusive supervision. Based on above indirect evidences in the literature, it is hypothesized that:

$\mathbf{H}_{4}$ : Supervisor cynicism mediates the relationship between supervisor perception of organizational hypocrisy and abusive supervision.

\subsection{Moderation Relationship}

Research has shown that dispositional characteristics of the employee interact with situational characteristics of the organizations towards the development of cynicism (Naus, 2007). However, constraints may reduce the likelihood that a given situational perception is related to deviant behaviour (Robinson \& Bennett, 1995). Specifically, Colbert et al., have observed that employees' personality traits may serve to constrain or suppress the relationship between unfavourable perceptions of the situation and workplace deviance; thus, employees are more likely to engage in workplace deviant behaviours when they have unfavourable perceptions of the work situation and when their personality traits do not constrain them from engaging in deviant behaviour (Colbert, Mount, Harter, Witt, \& Barrick, 2004). Colbert's observations are supported further by Berkowitz's reformulation of frustration aggression theory (1989) and the meta-analytic review of Marcus-Newhall, Pedersen, Carlson, and Miller (2000) reveals that negativity of the setting in which the provocateur and the participant interact is an important theoretical moderator of the relationship between perceptions of mistreatment and hostility by the participant. Extrapolating these findings on the possible outcomes of organizational hypocrisy it can be conjectured that if negative personality traits support the emergence of abusive supervision then, resilience being a positive personality characteristic should weaken the relationship between supervisor perceptions of 
organizational hypocrisy (involving a sense of mistreatment) and abusive supervision (aggression).

Ford observes that although the image of organization as perceived by its employee is important yet the relationship between some individual factors that may influence the perceptions of internal stakeholders about organizational credibility is not fully clear (Ford, 2016). And king and colleagues noted that there has been a growing importance of resilience in the workplace as found in psychological capital and positive organizational scholarship but little research has examined its influence on work outcomes. The construct "has been recognized in theory, measurement, and research for a number of years in other fields (e.g., clinical and developmental psychology) and applied to the workplace at all levels of analysis, but it still needs much better understanding, and is severely under-researched in Organizational Behavior" (King, Newman, \& Luthans, 2016).

In the extent literature resilience is taken in two different meanings. Firstly, scholars who have defined it as trait regard it as individuals' capacity that helps them deal with adversity and adjust positively to the workplace environment (Jackson, Firtko, \& Edenborough, 2007). According to this definition the individuals high in resilience have the capacity to move on in a positive way though their experiences are negative (Block \& Kremen, 1996; Michele M. Tugade \& Fredrickson, 2004). By second group of the scholars it has been defined as "a dynamic process encompassing positive adaptation within the context of significant adversity" (Luthar, Cicchetti, \& Becker, 2000). This conceptualization of scholars regards resilience as a state that can be developed or diminished. Evidence in support of this conceptualization is growing. It has been found that cognitive transformation and personal growth training can lead to development of resilience (Tebes, Irish, Puglisi Vasquez, \& Perkins, 2004). Research on psychological capital reveals state-like nature of the PsyCap and hence this also supports the view that resilience being a component of PsyCap, can be developed also (Luthans, 2002; Luthans, Avey, Avolio, \& Peterson, 2010).

The mechanism through which resilience diminishes negative outcomes by engagement in meaningful activities have been found to be positive emotions, 
psychological flexibility and needs satisfaction (Goubert \& Trompetter, 2017). Nakamura and Csikszentmihalyi (2014) observe that frustration is not always directed towards aggressive response but it can be a source of growth as well (Davitz, 1952). Resilience has been viewed as an important personality trait that may account for the individuals ability to adapt to adversity and manage, and transform life stressors (Fredrickson, 2004; Michele M Tugade \& Fredrickson, 2007). It is therefore hypothesized that:

$\mathbf{H}_{5}$ : Supervisor resilience moderates the relationship between supervisor perceptions of organizational hypocrisy, supervisor cynicism and abusive supervision inversely.

\section{RESEARCH METHODOLOGY}

\subsection{Participants and Procedure}

In the light of observation of Zechmeister and Posavac (2003) a study should be based on a comprehensive strategy regarded as research design of the study. The purpose of the study is to understand the occurrence of abusive supervision under the influence of supervisors' perception of organizational hypocrisy as immoral through a mediating mechanism; Organizational cynicism mediates the relationships. Moreover, the study endeavours to investigate the moderating role of supervisors' moral self-identity and supervisor resilience in the relationship between supervisors' perceived organizational hypocrisy with abusive supervision. The model has been developed on the basis of gap that was identified during the study of the literature.

The development of hypotheses of the study have been done using a deductive research approach. Though some authors have considered it value laiden and less objective yet it is much desired method of researchers to solve social problems (Powell, 2019) has been observed to have higher methodological transparency than other approaches (Aguinis, Ramani, \& Alabduljader, 2018). Accordingly, in the light of theory a quantitative research design has been envisaged for this study. This study is designed as cross sectional study which usually depends on field survey (Rizvi, 2016) which is deemed appropriate for measurement of behaviours and attitudes of employees (Naseer, Raja, Syed, Donia, \& Darr, 2016). However best efforts were made to design an interesting questionnaire based on principles of surveytainment to avoid straight lining 
and other problems associated with self-report questioners (Kostyk, Zhou, \& Hyman, 2019).Data collection has been done during these surveys using existing validated instruments for the constructs being studied. This study has taken employees as the unit of analysis. Overall, this study follows the positivist philosophy of research and is based on observations in natural environment setting without any interference in it and the observations can be repeated as such.

Present study is based on data collected from multiple sources (self-reported and peer-reported). Supervisors were measured for organizational hypocrisy, organizational cynicism, moral self-identity, and resilience and the subordinates of these supervisors have been measured for their perceptions of abusive supervision variables. The data for examining the hypothesised relationships was collected over three-time spans. Independent variable (Organizational Hypocrisy) was collected at $\mathrm{t} 1$ and mediator (organizational cynicism) and abusive supervision were tapped on $\mathrm{t} 2$ whereas moderating variablee (moral identity and resilience) was tapped on time 3.

Data collection for this study was done by pooling a sample of supervisor and their subordinates from 33 public and private sector organizations spread throughout the Pakistan, through convenient sampling technique. With the intent to increase generalizability of findings of the study, employees of 33 various formations from four provinces of the country, with different social moorings and cultural norms were requested to take part in the study. The selection of these participants was randomly made out of 33 directories of the formations. The e-mail addresses of the participants and phone numbers were obtained and a total of 600 of the contacted supervisors agreed to participate in the study. Four hundred and properly thirty-one (paired) responses were received. The final useable responses consisted of 420 supervisor- employee dyads after the data was merged. Thus, a total response rate of $70 \%$ was attained.

\subsection{Measures}

Already developed scales tested for high reliability were adopted for the study with ado. To avoid confusion and participation, all the scales were converted to 7- box Likert scales, throughout the final questionnaire, ranging from 1 (Strongly Disagree) to 7 (Strongly Agree). 


\subsection{Supervisor perceptions of organizational hypocrisy}

The organizational hypocrisy was taped at time wave-1 with 17 items scale developed by Kıliçoğlu et al. (2017). A slight change in the wording of items had to be made to fit the scale to this study: the words of "school" and "principal" were replaced with the words like "organization" and "management". The examples of items with likewise changes are: "Our organization reflects the environment's norms" and "Although organization management say that they will solve problems in the organization,"

The creators of the scale have conceptualized it to measure three-dimensional construct of organizational hypocrisy. This study has used the construct in aggregate and it was observed after CFA results for one factor organizational hypocrisy model (CMIN/ $\mathrm{Df}=1.35, \mathrm{p}<0.001, \mathrm{CFI}=.987, \mathrm{NFI}=.951, \mathrm{GFI}=.96, \mathrm{AGFI}=.946 \mathrm{RMSEA}=.029$, PCLOSE $=1.00)$ show an acceptable model fit. The $\alpha$-reliability of the scale was found to be equal to .91 .

\section{Supervisor cynicism}

On the bases of literature review, it is considered that the most suitable scale that could be used for measurement of supervisors' cynicism was OCS (organizational cynicism scale) scale developed by Brandes, Dharwadkar, and Dean (1999). The scale included 13 items to capture three dimensions of organizational cynicism: affective (5 items), cognitive ( 3 items) and behavioural (5 items). The sample questions are: "I believe that my company (my organization) says one thing and does another." and "When I think about my organization, I get angry". Cronbach's Alpha $(\alpha)$ was found to be .89 in this study.

OCS has been constructed as a three dimensional scale. However, the CFA results for aggregate model, as used in this study, $(\mathrm{CMIN} / \mathrm{Df}=2.18, \mathrm{CFI}=.965$, NFI $=$ $.93, \mathrm{GFI}=.954, \mathrm{AGFI}=.930, \mathrm{RMSEA}=.05$ and PCLOSE $=.319$.) showed a good fit.

\section{Abusive Supervision}

Abusive supervision behaviour was gauged by using abusive supervision scale developed by Tepper (2000). The scale consists of 15 -item. The items illustrative of this scale are (read the items Using the prefix "my boss") "tells me my thoughts or feelings are stupid" and "blames me to save himself/herself embarrassment." The internal 
reliability of the scale was tested through Cronbach alpha which stood out at good value value $(\alpha=.88)$.

\section{Supervisor Resilience}

To capture resilience Block and Kremen (1996) Ego-Resiliency Scale consisting of 14-item on was used. The scale included items like "I enjoy dealing with new and unusual situations". This published scale has established psychometrics and substantial empirical support. The Cronbach alpha of the measure for resilience has been tested to be .92 .

\section{Control variables}

Prior research has suggested that supervisor demographic variables affect abusive supervision (Mackey et al., 2017;Tepper et al., 2011;Zhang \& Bednall, 2016). We therefore controlled for supervisor participants' age, gender, and organizational tenure during data analysis to get a clearer estimation of the studied effects.

\section{Analytical Strategy}

For testing hypotheses and to examine the symmetric relationship between IV and DV researchers traditionally conduct data analysis (Mikalef, Boura, Lekakos, \& Krogstie, 2019). We adopted simple regression as our analytic strategy to test direct effects, mediation and moderated mediation. The hypothesized relationships were tested using simple linear regression and PROCESS macro for SPSS developed by Hayes and Preacher (2013) and Hayes (2019). We ran three sets of analyses for testing moderated mediated relationships of the conceptualized model. Firstly, we used simple linear regression and then we used Model- 4 of the macro for testing mediation relationship (Hypotheses 1, 2, 3 \&4). Secondly, we combined the moderator into our model and tested an overall moderated-mediation model (Hypotheses-5) by utilizing Model-7 of the PROCESS macro. The macro was used to mean canter the continuous variables before executing this part of the analysis as suggested by Aiken, West, and Reno (1991).

\subsection{Validating the Measurement Model}

To establish the discriminant validity of the study variables first exploratory factor analysis was conducted using SPSS-26 which showed four factor solution for the collected data. All items of the constructs demonstrated acceptable factor loading above 
0.4 ranging from .48 to .78 which confirmed the convergent validity of the construct (for details see Table1 below).

\begin{tabular}{|c|c|c|c|c|}
\hline \multicolumn{5}{|l|}{ Table 1. Factor Loadings } \\
\hline $\begin{array}{l}\text { Items of the } \\
\text { Questionnaire }\end{array}$ & $\begin{array}{l}\text { Factor1 } \\
\text { SupPOH }\end{array}$ & $\begin{array}{l}\text { Factor2 } \\
\text { SupR }\end{array}$ & $\begin{array}{l}\text { Factor3 } \\
\text { AbSup }\end{array}$ & $\begin{array}{l}\text { Factor4 } \\
\text { SupC }\end{array}$ \\
\hline Item 1 & .603 & .275 & .580 & .621 \\
\hline Item 2 & .692 & .556 & .589 & .669 \\
\hline Item 3 & .676 & .686 & .630 & .569 \\
\hline Item 4 & .709 & .741 & .561 & .565 \\
\hline Item 5 & .641 & .714 & .610 & .507 \\
\hline Item 6 & .648 & .730 & .642 & .705 \\
\hline Item 7 & .735 & .687 & .615 & .678 \\
\hline Item 8 & .717 & .638 & .605 & .733 \\
\hline Item 9 & .637 & .745 & .604 & .647 \\
\hline Item 10 & .655 & .616 & .698 & .662 \\
\hline Item 11 & .689 & .692 & .658 & .652 \\
\hline Item 12 & .695 & .703 & .625 & .564 \\
\hline Item 13 & .614 & .735 & .648 & .685 \\
\hline Item 14 & .56 & .653 & .624 & \\
\hline Item 15 & .690 & & .666 & \\
\hline Item 16 & .611 & & & \\
\hline Item 17 & .690 & & & \\
\hline
\end{tabular}

Analysis with Amos Plugin of SPSS-26 for checking the goodness of fit also showed results indicating good fit. Model fit indices included CMIN/ Df $=1.29$, $\mathrm{p}<0.001, \mathrm{GFI}=.874, \mathrm{CFI}=.948, \mathrm{NFI}=.806, \mathrm{GFI}=.843, \mathrm{AGFI}=.833, \mathrm{RMSEA}=.026$ and PCLOSE $=1.000$. 


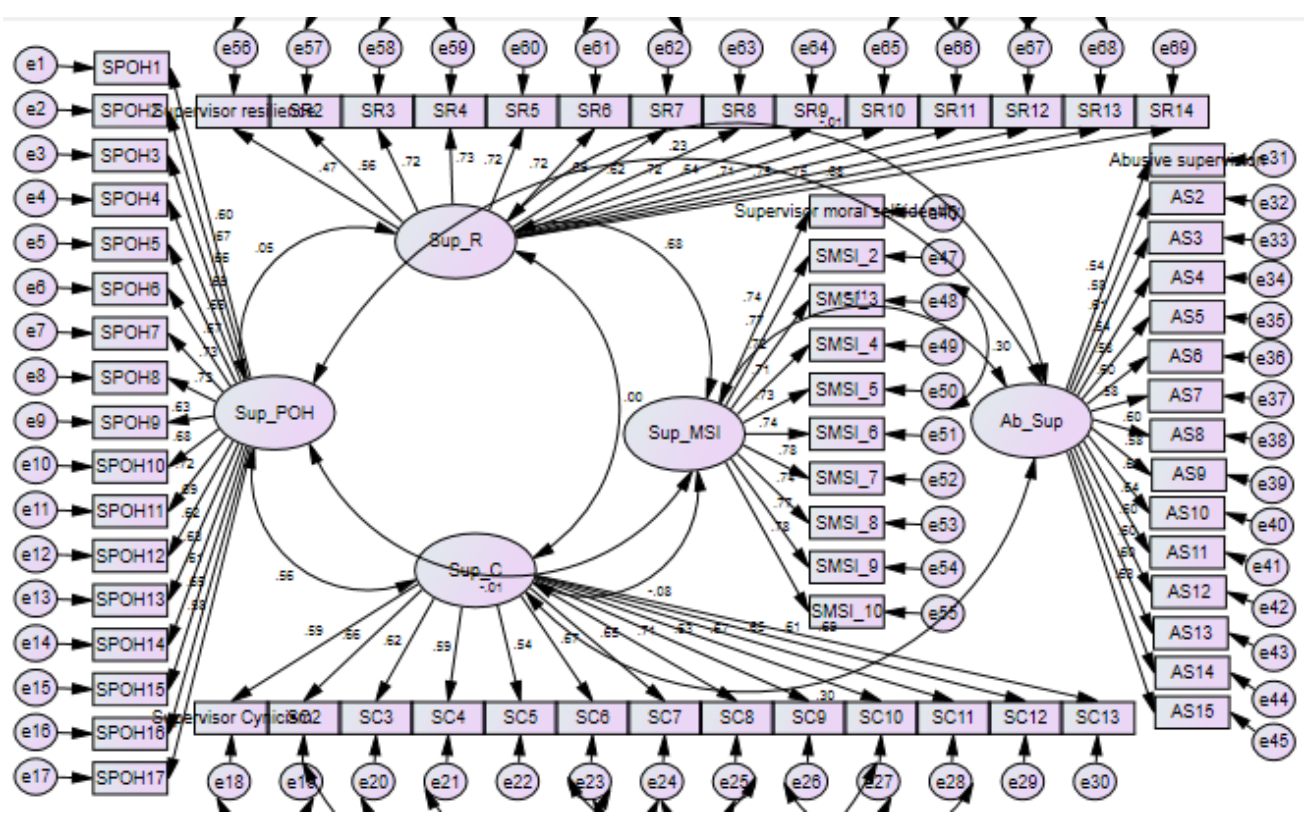

Figure 2. CFA for testing measurement model fit

\section{RESULTS AND ANALYSIS}

\subsection{Descriptives and Correlation Matrix}

Descriptive statistics like means, standard deviations, among the key variables of the study are laid down in Table-2. The participants were full time employed (working 40 hours per week or more), Their average age was $32 . .80$ years (with $\mathrm{SD}=6.54$ ) in an age bracket of 24 to 60 years, and their average length of job stay in organization was 13.03 years ranging from $1-54$ years $(\mathrm{SD}=11.00)$. Female participants constituted 26.2 $\%$ of the studied sample

\begin{tabular}{|c|c|c|c|c|c|}
\hline \multicolumn{1}{|l|}{ Table 2. Descriptive statistics } \\
\hline & $\mathrm{N}$ & Minimum & Maximum & Mean & Std. Deviation \\
\hline Employee Gender & 420 & 1.00 & 2.00 & 1.2619 & .44020 \\
\hline Employee Age & 420 & 23.00 & 62.00 & 32.8024 & 6.54753 \\
\hline Organizational Tenure & 420 & 1.00 & 54.00 & 13.0333 & 11.00765 \\
\hline $\begin{array}{c}\text { Name of Employee } \\
\text { organization }\end{array}$ & 420 & 1.00 & 33.00 & 12.7238 & 9.02661 \\
\hline Public or Private sector & 420 & 1.00 & 2.00 & 1.5262 & .49991 \\
\hline SupPOH & 420 & 1.06 & 7.00 & 5.2983 & 1.14786 \\
\hline
\end{tabular}




\begin{tabular}{|c|c|c|c|c|c|}
\hline AbSup & 420 & 1.00 & 7.00 & 4.6957 & 1.13259 \\
\hline SupC & 420 & 1.15 & 6.85 & 5.0183 & .90480 \\
\hline SupR & 420 & 1.00 & 6.57 & 3.5905 & 1.35820 \\
\hline Valid N (listwise) & 420 & & & & \\
\hline
\end{tabular}

As shown in the table below, three theoretical variables i.e perceived organizational hypocrisy, supervisor cynicism and abusive supervision were found to be significantly correlated in the conceptualized direction whereas Supervisor resilience was not found to have any correlation with IV $\mathrm{M}$ and DV.

\begin{tabular}{|l|l|c|c|c|c|}
\hline \multicolumn{2}{|l|}{} & SupPOH & AbSup & SupC & SupR \\
\hline SupPOH & Pearson Correlation & 1 & $.212^{* *}$ & $.518^{* *}$ & .045 \\
\hline AbSup & Pearson Correlation & $.212^{* *}$ & 1 & $.275^{* *}$ & -.012 \\
\hline SupC & Pearson Correlation & $.518^{* *}$ & $.275^{* *}$ & 1 & -.004 \\
\hline SupR & Pearson Correlation & .045 & -.012 & -.004 & 1 \\
\hline **. Correlation is significant at the 0.01 level (2-tailed). \\
*. Correlation is significant at the 0.05 level (2-tailed). \\
\hline
\end{tabular}

\subsection{Testing of Hypotheses}

Statistical testing of the study hypotheses was carried out through a series of tests. The results of Table-4 below show the statistics of the direct relationship of IV with DV. They present the relationship as significant (Sig =.000) and coefficient of the relationship of SupPOH and AbSup as positive $(\beta=.21)$.

\begin{tabular}{|c|c|c|c|c|c|c|}
\hline \multicolumn{7}{|c|}{ ANOVAa } \\
\hline \multicolumn{2}{|c|}{ Model } & Sum of Squares & df & Mean Square & $\mathbf{F}$ & Sig. \\
\hline \multirow[t]{3}{*}{1} & Regression & 24.073 & 1 & 24.073 & 19.600 & $.000^{\mathrm{b}}$ \\
\hline & Residual & 513.399 & 418 & 1.228 & & \\
\hline & Total & 537.472 & 419 & & & \\
\hline \multicolumn{7}{|c|}{ Coefficients $^{\mathbf{a}}$} \\
\hline \multirow{2}{*}{\multicolumn{2}{|c|}{ Model }} & \multicolumn{2}{|c|}{ Unstandardized Coefficients } & Standardized Coeffs & \multirow[b]{2}{*}{$\mathbf{t}$} & \multirow[b]{2}{*}{ Sig. } \\
\hline & & B & Std. Error & Beta & & \\
\hline \multirow[t]{2}{*}{1} & (Constant) & 3.589 & .256 & & 14.038 & .000 \\
\hline & SupPOH & .209 & .047 & .212 & 4.427 & .000 \\
\hline
\end{tabular}


Next, the analysis of the results of executing model-4 as shown in table 5 below, reveal that $\mathrm{SupPOH}$ is associated positively with supervisor cynicism (SupC) $(\beta=.3897$, $\mathrm{t}=11.8144, \mathrm{p}<.000)$, and SupC is positively related with AbSup $(\beta=.2652, \mathrm{t}=3.8099$, $\mathrm{p}<.01)$. Moreover, SupPOH is found to have significant indirect effect on abusive supervision via supervisor cynicism (completely standardised indirect effect $=.1048$, $\mathrm{SE}=.0325)$ whereas the direct effect of organizational hypocrisy on $\mathrm{Y}$ became insignificant when mediator is introduced in the model.

Full mediation takes place when the direct effect of $\mathrm{x}$ on $\mathrm{y}$ is significant only in the absence of mediator but in the presence of mediator it becomes insignificant whereas the indirect effect is significant (Hayes, 2012). As it can be seen in Table-3, the indirect effect of independent variable and the mediated effect of organizational cynicism on abusive supervision are significant. These results confirm Hypotheses 2, 3 and 4 of this study.

\begin{tabular}{|c|c|c|c|c|c|c|}
\hline Outcome variable: SupC & $B$ & $S E$ & $T$ & $P$ & $R 2$ & $p$ \\
\hline & & & & & .298 & .000 \\
\hline Constant & 2.2449 & .2599 & 8.6367 & .0000 & & \\
\hline SupPOH & .3897 & .0330 & 11.8144 & .0000 & & \\
\hline Gender & .2604 & .0874 & 2.9795 & .0031 & & \\
\hline Age & .0118 & .0064 & 1.8353 & .0672 & & \\
\hline OrgTen & -.0006 & .0039 & -.1455 & .8844 & & \\
\hline \multicolumn{7}{|l|}{ Outcome variable: } \\
\hline & & & & & .0938 & .000 \\
\hline Constant & 2.6655 & .4004 & 6.6576 & .0000 & & \\
\hline SupPOH & .0947 & .0541 & 1.7505 & .0808 & & \\
\hline SupC & .2652 & .0696 & 3.8099 & .0002 & & \\
\hline Gender & .1163 & .1253 & .9289 & .3535 & & \\
\hline Age & -.0023 & .0092 & -.2532 & .8002 & & \\
\hline OrgTen & .0097 & .0055 & 1.773 & .0769 & & \\
\hline \multirow{2}{*}{$\begin{array}{l}\text { Direct effect of SupPOH on } \\
\text { AbSup }\end{array}$} & Effect & SE & \multicolumn{2}{|c|}{ LLCI } & \multicolumn{2}{|c|}{ ULCI } \\
\hline & .0947 & .0541 & \multicolumn{2}{|c|}{-.0116} & \multicolumn{2}{|c|}{.2010} \\
\hline $\begin{array}{l}\text { Indirect effect of SupPOH on } \\
\text { AbSup }\end{array}$ & Effect & BootSE & \multicolumn{2}{|c|}{ BootLLCI } & \multicolumn{2}{|c|}{ BootULCI } \\
\hline SupC & .1034 & \multicolumn{2}{|c|}{.0322} & .0438 & \multicolumn{2}{|c|}{.1701} \\
\hline
\end{tabular}


In case of reverse moderation, the beta value of independent variable is decreased. However, the significance of the interaction term's coefficient should be of primary focus in checking for moderation. Moreover, when conditional effect is significant at different levels, the moderating variable inversely moderates the relation between IV and DV (Hayes, 2012). The moderation effects of supervisor resilience (SupR) on organizational cynicism and then abusive supervision were tested using model-7 of the Process Macro.

The results of these moderation effects can be viewed in tables- 6 below. It can be noted that when interaction term of supervisor resilience (Sup_R; W) supervisors' perceived organizational hypocrisy (Sup_POH; X), are regressed on abusive supervision (Ab_Sup through SupC), the above mentioned conditions of moderation are fulfilled. Firstly, Moderation decreases the beta value $(\beta)$ of supervisor perceived organizational hypocrisy on organizational cynicism $(\beta=0.3620, p=0.000$, Table- 6 ) compared with the effect of the independent variable alone on supervisor cynicism $(\beta=0.3897, \mathrm{p}=.000$ Table 5) before introduction of moderator. Secondly, the values of interaction term $\left(\mathrm{X}^{*} \mathrm{~W}=-0.1911\right.$, with $\mathrm{p}=0.000$ predicting an $\mathrm{R} 2$ Change of $11 \%$ in the model) are significant. And lastly, the conditional effect of $\mathrm{X}$ on $\mathrm{Y}$ at values of the moderator varies inversely and significantly at the levels of moderator (SupR) as hypothesized in the study. This indicates that the effect of $\mathrm{X}$ (organizational hypocrisy) on $\mathrm{M}$ (organizational cynicism) and then $\mathrm{Y}$ (abusive supervision), moves towards lower level in negative direction and significantly as $\mathrm{W}$ move from its low, to high levels through its moderate levels.

The Moderated mediation Hypotheses (H5) is further confirmed by the results showing a significant index of moderated mediation $($ Index $=-.0507$, BootSE $=.0157$ with no zero falling between Boot LLCI and BootULCI values). 


\begin{tabular}{|c|c|c|c|c|c|c|c|}
\hline \multicolumn{8}{|c|}{ Table 6. Moderating effect of Resilience } \\
\hline \multicolumn{2}{|l|}{$\begin{array}{l}\text { X/W/Int term/ } \\
\text { Controls/SupC }\end{array}$} & Coefficient & $S E$ & $L L C I$ & $U L C I$ & $R 2$ & $P$ \\
\hline & & & & & & .4103 & .000 \\
\hline \multicolumn{2}{|c|}{ Constant } & 4.3162 & .2067 & 3.9100 & 4.7224 & & \\
\hline \multicolumn{2}{|c|}{ SupPoh on SupC } & .3620 & .0304 & .3022 & .4218 & & \\
\hline \multicolumn{2}{|c|}{ SupR } & .0199 & .0259 & -.0310 & .0707 & & \\
\hline \multicolumn{2}{|c|}{ Int_term } & -.1911 & .0210 & -.2324 & -.1498 & & \\
\hline \multicolumn{2}{|c|}{ Gender } & .2843 & .0813 & .1244 & .4442 & & \\
\hline \multicolumn{2}{|l|}{ Age } & .0116 & .0059 & .0000 & .0233 & & \\
\hline \multicolumn{2}{|l|}{ OrgTen } & -.0020 & .0035 & -.0089 & .0050 & & \\
\hline \multicolumn{2}{|c|}{ SupC on AbSup } & .2652 & .0696 & .1284 & .4021 & & \\
\hline \multicolumn{2}{|c|}{$\begin{array}{c}\text { Index of Moderated } \\
\text { Mediation }\end{array}$} & Index & BootSE & BootLLCI & $\begin{array}{c}\text { BootU } \\
\text { LCI }\end{array}$ & & \\
\hline \multicolumn{2}{|l|}{ SupR } & -.0507 & .0157 & -.0832 & -.0213 & & \\
\hline \multicolumn{8}{|c|}{ Conditional Indirect Effect of $\mathrm{X}$ on $\mathrm{Y}$ at Values of the Moderator: } \\
\hline Focal Predictor & SupR & Effect & BootSE & BootLLCI & $\begin{array}{l}\text { BootU } \\
\text { LCI }\end{array}$ & & \\
\hline \multirow{3}{*}{ SupPOH } & -1.447 & .1694 & .0498 & .0730 & .2700 & & \\
\hline & -.0190 & .0970 & .0293 & .0421 & .1562 & & \\
\hline & 1.6952 & .0101 & .0155 & -.0198 & .0442 & & \\
\hline
\end{tabular}

These results show that hypotheses H5 is affirmed positively. The Graphical presentation of the interactive effect of supervisor resilience with organizational hypocrisy is as under:

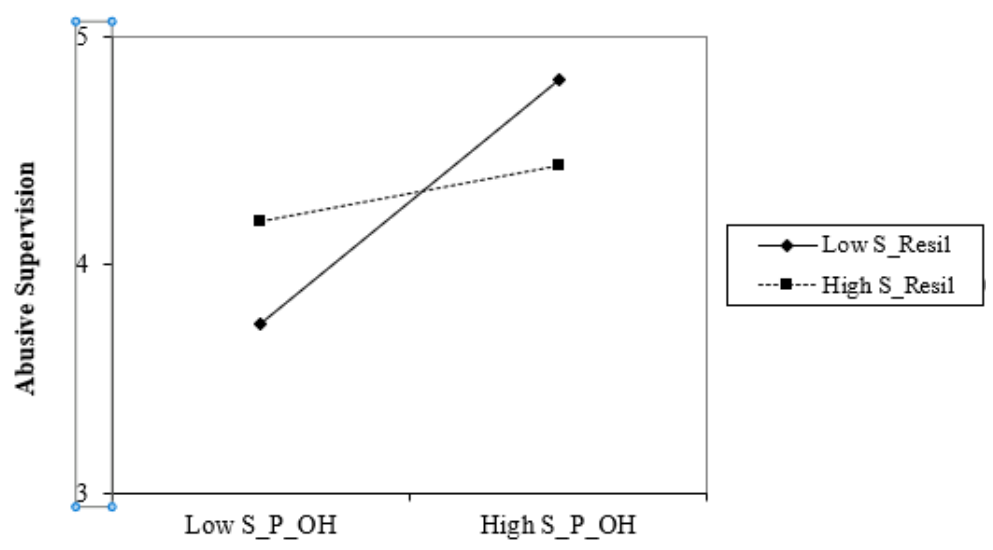

Figure 3. Graphical presentation of moderation effect 


\section{DISCUSSION}

It has been noted that despite a recent meta-analytic review about antecedents of abusive supervision (Zhang \& Bednall, 2016) the impact of a number of organizational characteristics on emergence of abusive supervision has yet to be explored by the researchers of the field. The observations of Newman, Round, Bhattacharya, and Roy (2017) about ethical climates in organizations suggests that organizations lacking in standards or norms for decision making may develop un-ethical organizational culture. And, both types of empirical evidences in favour as well as against the validity of the displaced aggression theory are available in social psychology literature and scholars have considered it a reliable phenomenon (N. Miller, Pedersen, Earleywine, \& Pollock, 2003).

Following the objective of research statistical analyses rendered good support for all the conceptualized hypotheses. Previously, numerous scientific studies have demonstrated the existence of negative attitudes originating from adverse working conditions (Naus, 2007). The already tested relationship of organizational hypocrisy with organizational cynicism and the relationship of organizational cynicism with abusive supervision have been re-affirmed. The freshly established relationships of organizational hypocrisy with abusive supervision and then organizational cynicism as a mediator of this relationship have not been studied before. Findings of the study have affirmed these relationships statistically. Most importantly this study has tested a reverse moderated mediating effect of supervisor resilience on these direct and mediating relationships.

Although previous studies have analysed the antecedents of abusive supervision but the mechanism through which organizational characteristics effect abusive supervision and how it can be avoided has been unexplored through a single model especially in Pakistani context. This is likely the first empirical study in Pakistan that tests the emergence of abusive supervision as a dynamic result of interplay of three types of factors utilizing frustration-aggression-displacement theory of Dollard et al. (1939) supported by Friedrickson's broaden and build theory, (2004). It is hoped that the study may advance the understanding of when and why individuals would be more or less 
engaged in immoral behaviours like abusive supervision when organizations fail to meet societal expectations whereas positive perceptions of CSR create job embededness and decreased turnover (Ng, Yam, \& Aguinis, 2019) because employees including supervisors consider it as moral act of organizations. This is first study of its type to provide a parsimonious theoretical explanation for the translation of organizational hypocrisy into abusive behaviours of supervisors at workplace and how these can be controlled. Research studies have shown that creative responding to the stressful situations at workplace can increase resilience of individuals (Cha \& Roberts, 2019) which implies that resilient people employee creative strategies to handle tough situations that can be frustrating.

The current study has important practical implications. Firstly, organizations may wish to re-examine their management philosophy to develop a culture of "walk the talk" and keeping its promises. The organizational practices related to hypocrisy and resultant behaviours of supervisors, who have to implement organizational decisions without having a complete knowledge of how and why these decisions were reached at by the management, appear to be petty in day to day work life but they can not only be immensely important towards depleting the health and wellbeing of the organizational members but they can also be a Damocles sword for growth of trustworthy relations in organizations in particular and organizations relations with society in general. And when supervisor level employees experience negative emotions like stress, anguish and intentions to sabotage (K1lı̧̧oğlu, K1lı̧̧oğlu, \& Karadağ, 2019; F. Naus, A. Van Iterson, $\&$ R. Roe, 2007), as a result of organizational hypocritical policies and practices, then disaster of the organization is unavoidable. Hence the top management should do more to bring their words in practice. Not walking the talk may reconcile the discordant demands of the stakeholders but walking the talk will buy long term loyalty of the stakeholders even if they become annoyed for the time being when their demands are not met by the organizations in the long term interest of the organization.

Secondly, This work is also a soft reminder to the employees of the organizations in general and main implementers of the organizational policies and practices i.e. the supervisors, in specific that they can shield the tide of abuse unleashed by organizational 
climatic factors even if the top management fails to take cognizance of the hypocritical organizational practices under duress of the business pressures. An employee who focuses on his own self-development even in odd circumstance is an asset for the organization rather than a liability. At the end of the day it is one's own choice; should he fall prey to self-fulfilling traps of negative perceptions and abusive behaviours that are intended to mitigate immoral practices or should he be resilient and be forbearing. A supervisor can actually unleash a vicious cycle of negativity in response to negativity leading to irreparable damage to not only his own health by experiencing regret and feelings of remorse after committing bad behaviours (Haggard \& Park, 2018) or be high in resilience and have a nourishing feelings of having contributed positivity to the organization as well as society.

Thus ensuring practice of good management is not just the responsibility of either one of the employees or managers, it is the responsibility of both. As the industrial organizational psychologists observe, there are dual results when everything works in its place. Organizations viability is truly ensured through the wellbeing of the organizational members. More importantly, employees can make organizations work not through tit for tat but way but by gaining knowledge of the working of organization in its complex environment and by practicing positive reciprocity rather than negative reciprocity principle.

Lastly, the HRD practitioners should focus the training programmes of the organization on development of resilience in employees to fill the gaps that may be left as a result of faulty recruitments. Organizations should design interventions for developing a culture for self-growth in employees and supervisors and this would be perhaps the best way to stop the negativity from being epidemic and individual psychological resources from waning away endlessly. Organizations may wish to encourage employees to use employee assistance programs and to identify more productive strategies of conserving and attaining resources e.g. mentoring to give honest feedback to employees (Tepper et al., 2011) in a clear cut manner.

\section{LIMITATIONS AND FUTURE RESEARCH DIRECTIONS}

Although the present study possesses theoretical and methodological strengths, 
yet like every study it carries some limitations which provide an opportunity to the researchers to further fine tune for expanding the abusive leadership domain in future. Firstly, the current study utilized a research design with data collected temporally separated waves; however, it cannot be classified as a full longitudinal design. In future, the researchers can employ more longitudinal design wherein all the studied variables are tapped at more than one time intervals.

Secondly, the scale used for measurement of perceived organizational hypocrisy based on observations of supervisors only. As the construct consists of three elements (Kılıçoğlu et al., 2017), more accurate scales and suitable study designs developed for its measurement in future might be able to tap the observations of external as well as internal stake holders for more accurate measurement of effect size of organizational hypocrisy on supervisor organizational cynicism and abusive supervision.

Thirdly, though the data was collected from diverse sources yet the difference in impact, if any, of the sector could not be analysed. Future researchers could adopt a mixed quantitative and qualitative design to differentiate between the effects of specific sector on emergence of abusive supervision.

And lastly just as abusive supervision can create feelings of dehumanization of subordinates (Caesens, Nguyen, \& Stinglhamber, 2019) in the same way organizational factors can create emotions of dehumanization in supervisors which may lead to abusive supervision. In future scholars may study the mediating role of dehumanization between the relationships of organizational hypocrisy abusive supervision.

\section{CONCLUSION}

Ford (2016) has observed that if organizational stake holders have negative perceptions of an organization's credibility, then that organization might have to pay dire economic and social costs. This study seeks how excessive inclinations of organizations to survival and less towards action may backfire. It aimed at testing empirically why and how organizational hypocrisy is a source of unethical choice of behaving abusively by the supervisors. Our findings contribute to our knowledge of the antecedents of abusive supervision by (a) highlighting that supervisor cynicism is critical factor behind abusive 
supervision, (b) illustrating from the perspective of FAD theory, that supervisor's failure to be a resilient self is an underlying mechanism through which abusive supervision emerges at workplace.

\section{REFERENCES}

Abraham, R. (2000). Organizational cynicism: Bases and consequences. Genetic, social, and general psychology monographs, 126(3), 269.

Aguinis, H., Ramani, R. S., \& Alabduljader, N. (2018). What you see is what you get? Enhancing methodological transparency in management research. Academy of Management Annals, 12(1), 83-110.

Aiken, L. S., West, S. G., \& Reno, R. R. (1991). Multiple regression: Testing and interpreting interactions: Sage.

Allen, J. J., \& Anderson, C. A. (2017). General aggression model. The International Encyclopedia of Media Effects, 1-15.

Alvesson, M. (2020). Critical performativity in practice: the chronicle as a vehicle for achieving social impact. European Journal of Work and Organizational Psychology, 1-8.

Andersson, L. M. (1996). Employee cynicism: An examination using a contract violation framework. Human relations, 49(11), 1395-1418.

Appelbaum, S. H., laconi, G. D., \& Matousek, A. (2007). Positive and negative deviant workplace behaviors: causes, impacts, and solutions. Corporate Governance: The international journal of business in society.

Archimi, C. S., Reynaud, E., Yasin, H. M., \& Bhatti, Z. A. (2018). How perceived corporate social responsibility affects employee cynicism: The mediating role of organizational trust. Journal of Business Ethics, 151(4), 907-921.

Argyris, C., \& Schon, D. A. (1974). Theory in practice: Increasing professional effectiveness: Jossey-Bass.

Ashforth, B. E. (1997). Petty tyranny in organizations: A preliminary examination of antecedents and consequences. Canadian Journal of Administrative Sciences/Revue Canadienne des Sciences de l'Administration, 14(2), 126-140.

Aslam, U., Muqadas, F., Imran, M. K., \& Rahman, U. U. (2018). Investigating the antecedents of work disengagement in the workplace. Journal of Management Development.

Bamberger, P. A., \& Bacharach, S. B. (2006). Abusive supervision and subordinate problem drinking: Taking resistance, stress and subordinate personality into account. Human relations, 59(6), 723-752.

Bandura, A. (1977). Self-efficacy: toward a unifying theory of behavioral change. Psychological review, 84(2), 191.

Bedeian, A. G. (2007). Even if the Tower Is "Ivory," It Isn't "White:" Understanding the Consequences of Faculty Cynicism. Academy of Management Learning and

Education, 6(1), 9-32.

Bedeian, A. G., Armenakis, A. A., \& Curran, S. M. (1981). The relationship between role stress and job-related, interpersonal, and organizational climate factors. The Journal of Social Psychology, 113(2), 247-260.

Berkowitz, L. (1989). Frustration-aggression hypothesis: Examination and reformulation. Psychological bulletin, 106(1), 59. 
Biron, M. (2010). Negative reciprocity and the association between perceived organizational ethical values and organizational deviance. Human relations, 63(6), 875-897.

Block, J., \& Kremen, A. M. (1996). IQ and ego-resiliency: conceptual and empirical connections and separateness. Journal of personality and social psychology, 70(2), 349.

Bommer, W. H., Rich, G. A., \& Rubin, R. S. (2005). Changing attitudes about change: Longitudinal effects of transformational leader behavior on employee cynicism about organizational change. Journal of Organizational Behavior: The International Journal of Industrial, Occupational and Organizational Psychology and Behavior, 26(7), 733-753.

Brandes, P., Dharwadkar, R., \& Dean, J. W. (1999). Does organizational cynicism matter? Employee and supervisor perspectives on work outcomes. Paper presented at the Eastern Academy of Management Proceedings.

Braun, S., Kark, R., \& Wisse, B. (2018). Fifty Shades of Grey: Exploring the Dark Sides of Leadership and Followership. Frontiers in psychology, 9, 1877.

Bromley, P., \& Powell, W. W. (2012). From smoke and mirrors to walking the talk: Decoupling in the contemporary world. Academy of Management Annals, 6(1), 483-530.

Brown, N. J., Sokal, A. D., \& Friedman, H. L. (2013). The complex dynamics of wishful thinking: The critical positivity ratio.

Brunsson, N. (1989). The organization of hypocrisy: Talk, decisions and actions in organizations: John Wiley \& Sons.

Brunsson, N. (1993). Ideas and actions: Justification and hypocrisy as alternatives to control. Accounting, Organizations Society, 18(6), 489-506.

Brunsson, N. (2007). The consequences of decision-making: Oxford University Press.

Byza, O. (2018). Leader-follower compatibility: how (dis-) similarities in values, social cynicism and leadership qualities relate to employee outcomes.

Byza, O. A., Schuh, S. C., Dörr, S. L., Spörrle, M., \& Maier, G. W. (2017). Are two cynics better than one? Toward understanding effects of leader-follower (in-) congruence in social cynicism. Journal of Organizational Behavior, 38(8), 1246 1259.

Caesens, G., Nguyen, N., \& Stinglhamber, F. (2019). Abusive supervision and organizational dehumanization. Journal of Business Psychology and Developing Societies, 34(5), 709-728.

Cha, S. E., \& Roberts, L. M. (2019). Leveraging Minority Identities at Work: An IndividualLevel Framework of the Identity Mobilization Process. Organization Science, 30(4), 735-760.

Christensen, L. T., Morsing, M., \& Thyssen, O. (2011). The polyphony of corporate social responsibility: Deconstructing accountability and transparency in the context of identity and hypocrisy. In Handbook of communication ethics (pp. 457-474): Lawrence Erlbaum Associates.

Colbert, A. E., Mount, M. K., Harter, J. K., Witt, L. A., \& Barrick, M. R. (2004). Interactive effects of personality and perceptions of the work situation on workplace deviance. Journal of Applied Psychology, 89(4), 599.

Cropanzano, R., \& Stein, J. H. (2009). Organizational justice and behavioral ethics: Promises and prospects. Business Ethics Quarterly, 19(2), 193-233.

Davitz, J. R. (1952). The effects of previous training on postfrustration behavior. The Journal of Abnormal and Social Psychology, 47(2S), 309. 
De Clercq, D., Rahman, Z., \& Haq, I. U. (2019). Explaining helping behavior in the workplace: The interactive effect of family-to-work conflict and Islamic work ethic. Journal of Business Ethics, 155(4), 1167-1177.

de Colle, S., \& Freeman, R. E. (2020). Unethical, neurotic, or both? A psychoanalytic account of ethical failures within organizations. Journal of Business Ethics: $A$ European Review, 29(1), 167-179.

De Cremer, D., Tenbrunsel, A. E., \& van Dijke, M. (2010). Regulating ethical failures: Insights from psychology. Journal of Business Ethics, 95(1), 1-6.

Dean Jr, J. W., Brandes, P., \& Dharwadkar, R. (1998). Organizational cynicism. Academy of management review, 23(2), 341-352.

Deng, H., Guan, Y., Bond, M. H., Zhang, Z., \& Hu, T. (2011). The Interplay between Social Cynicism Beliefs and Person-Organization Fit on Work-Related Attitudes among Chinese Employees. Journal of Applied Social Psychology, 41(1), 160 178.

Dollard, J., Miller, N. E., Doob, L. W., Mowrer, O. H., \& Sears, R. R. (1939). Frustration and aggression.

e.g. Carroll, A. B. (2000). Ethical challenges for business in the new millennium: Corporate social responsibility and models of management morality. Business Ethics Quarterly, 10(1), 33-42.

Eden, D. (2003). Self-fulfilling prophecies in organizations. Organizational behavior: $A$ management challenge, 87-120.

Eisenberger, R., Huntington, R., Hutchison, S., \& Sowa, D. (1986). Perceived organizational support. Journal of Applied Psychology, 71(3), 500.

Eissa, G., \& Lester, S. W. (2017). Supervisor role overload and frustration as antecedents of abusive supervision: The moderating role of supervisor personality. Journal of Organizational Behavior, 38(3), 307-326.

Eissa, G., Lester, S. W., \& Gupta, R. (2019). Interpersonal deviance and abusive supervision: The mediating role of supervisor negative emotions and the moderating role of subordinate organizational citizenship behavior. Journal of Business Ethics, 1-18.

Evans, W. R., Goodman, J. M., \& Davis, W. D. (2010). The impact of perceived corporate citizenship on organizational cynicism, OCB, and employee deviance. Human Performance, 24(1), 79-97.

Fernando, M., \& Gross, M. (2006). Workplace spirituality and organizational hypocrisy: The Holy Water-Gate Case.

Fine, G. A., \& Shulman, D. (2009g). Lies from the field: Ethical issues in organizational ethnography. Organizational ethnography: Studying the complexities of everyday life, 177-195.

Ford, L. A. (2016). Predictive Ability of Emotional Intelligence Scores on Employee SelfReported Perception of Comprehensive Organizational Credibility Inventory.

Fredrickson, B. L. (1998). What good are positive emotions? Review of general psychology, 2(3), 300-319.

Fredrickson, B. L. (2001). The role of positive emotions in positive psychology: The broaden-and-build theory of positive emotions. American Psychologist, 56(3), 218.

Fredrickson, B. L. (2004). The broaden-and-build theory of positive emotions. Philosophical Transactions of the Royal Society of London, 359(1449), 13671377.

Fredrickson, B. L., \& Branigan, C. (2001). The role of positive emotions in positive 
psychology: The broaden-and-build theory of positive emotions. 56(3), 218.

Fredrickson, B. L., \& Branigan, C. (2005). Positive emotions broaden the scope of attention and thought-action repertoires. Cognition \& emotion. 19(3), 313-332.

Fredrickson, B. L., \& Losada, M. F. (2005). Positive affect and the complex dynamics of human flourishing. American Psychologist, 60(7), 678.

Gonzalez-Morales, M. G., Kernan, M. C., Becker, T. E., \& Eisenberger, R. (2018). Defeating abusive supervision: Training supervisors to support subordinates. Journal of Occupational Health sychology, 23(2), 151.

Goswami, S., \& Ha-Brookshire, J. (2018). "I Quit": Retail Employees' Perceived Corporate Hypocrisy and Their Turnover Intentions.

Goubert, L., \& Trompetter, H. (2017). Towards a science and practice of resilience in the face of pain. European Journal of Pain, 21(8), 1301-1315.

Gouldner, A. W. (1960). The norm of reciprocity: A preliminary statement. American Sociological Review, 161-178.

Griffin, R. W., O'Leary-Kelly, A., \& Pritchard, R. D. (2004). The dark side of organizational behavior: Jossey-Bass San Francisco, CA.

Haggard, D. L., \& Park, H. M. (2018). Perceived supervisor remorse, abusive supervision, and LMX. Journal of Organizational Behavior, 39(10), 1252-1267.

Hale Jr, W. J., \& Pillow, D. R. (2015). Asymmetries in perceptions of self and others' hypocrisy: Rethinking the meaning and perception of the construct. European journal of social psychology, 45(1), 88-98.

Hayes, A. F. (2012). PROCESS: A versatile computational tool for observed variable mediation, moderation, and conditional process modeling. In: University of Kansas, $K S$.

Hayes, A. F. (2019). Process for SPSS and SAS (Version 3.3)[Macro]. In.

Hayes, A. F., \& Preacher, K. J. (2013). Conditional process modeling: Using structural equation modeling to examine contingent causal processes.

Hoobler, J. M., \& Brass, D. J. (2006). Abusive supervision and family undermining as displaced aggression. Journal of Applied Psychology, 91(5), 1125.

Huzzard, T., \& Östergren, K. (2002). When norms collide: Learning under organizational hypocrisy. British Journal of Management, 13(S2), S47-S59.

loannou, I., Kassinis, G. I., \& Papagiannakis, G. (2018). All are not saints, who go to church: Corporate social responsibility, perceived corporate hypocrisy and the impact on customer satisfaction. SSRN Electronic Journal. doi:10.2139/ssrn.3169241, (September 19, 2018).

Jackson, D., Firtko, A., \& Edenborough, M. (2007). Personal resilience as a strategy for surviving and thriving in the face of workplace adversity: a literature review. Journal of advanced nursing, 60(1), 1-9.

Jacqueminet, $A$. (2020). Practice implementation within a multidivisional firm: The role of institutional pressures and value consistency. Organization Science, 31(1), 182199.

Javed, B., Fatima, T., Yasin, R. M., Jahanzeb, S., \& Rawwas, M. Y. (2019). Impact of abusive supervision on deviant work behavior: The role of Islamic work ethic. Business Ethics: A European Review, 28(2), 221-233.

Johnson, J. L., \& O'Leary-Kelly, A. M. (2003). The effects of psychological contract breach and organizational cynicism: Not all social exchange violations are created equal. Journal of Organizational Behavior: The International Journal of Industrial, Occupational and Organizational Psychology and Behavior, 24(5), 627-647. 
Jordan, J., Mullen, E., \& Murnighan, J. K. (2011). Striving for the moral self: The effects of recalling past moral actions on future moral behavior. Personality and Social Psychology Bulletin, 37(5), 701-713.

Kanter, D. L., \& Mirvis, P. H. (1989). The cynical Americans: Living and working in an age of discontent and disillusion: Jossey-Bass.

Kılıçoğlu, G., Kılıçoğlu, D. Y., \& Karadağ, E. (2017). Do Schools Fail to "Walk Their Talk"? Development and Validation of a Scale Measuring Organizational Hypocrisy. Leadership and Policy in Schools, 1-31.

Kılıçoğlu, G., Kılıçoğlu, D. Y., \& Karadağ, E. (2019). Do schools fail to "walk their talk"? Development and validation of a scale measuring organizational hypocrisy. Leadership and Policy in Schools, 18(1), 52-82.

Kılıçoğlu, G., Yılmaz, D., \& Karadağ, E. (2014). Organizational hypocrisy in educational organizations: Do talk and decisions lead to inconsistent actions in schools. Paper presented at the European Conference on Educational Research, Porto, Portekiz.

Kim, S., Jung, K., Noh, G., \& Kang, L. K. (2019). What makes employees cynical in public organizations? Antecedents of organizational cynicism. Social Behavior Personality: an international journal, 47(6), 1-10.

King, D. D., Newman, A., \& Luthans, F. (2016). Not if, but when we need resilience in the workplace. Journal of Organizational Behavior, 37(5), 782-786.

Kish-Gephart, J. J., Harrison, D. A., \& Treviño, L. K. J. J. o. a. p. (2010). Bad apples, bad cases, and bad barrels: meta-analytic evidence about sources of unethical decisions at work. 95(1), 1.

Kleine, A. K., Rudolph, C. W., \& Zacher, H. (2019). Thriving at work: A meta-analysis. Journal of Organizational Behavior, 40(9-10), 973-999.

Kluemper, D. H., Mossholder, K. W., Ispas, D., Bing, M. N., Iliescu, D., \& Ilie, A. (2019). When core self-evaluations influence employees' deviant reactions to abusive supervision: The moderating role of cognitive ability. Journal of Business Ethics, 159(2), 435-453.

Koehn, D. (1999). What can eastern philosophy teach us about business ethics? Journal of Business Ethics, 19(1), 71-79.

Kostyk, A., Zhou, W., \& Hyman, M. R. (2019). Using surveytainment to counter declining survey data quality. Journal of Business Research, 95, 211-219.

Kuenzi, M., Mayer, D. M., \& Greenbaum, R. L. (2019). Creating an ethical organizational environment: The relationship between ethical leadership, ethical organizational climate, and unethical behavior. Journal of Personnel Psychology.

Lam, C. K., Walter, F., \& Huang, X. (2017). Supervisors' emotional exhaustion and abusive supervision: The moderating roles of perceived subordinate performance and supervisor self-monitoring. Journal of Organizational Behavior, 38(8), 1151 1166.

Lazarus, R. S. (1991). Progress on a cognitive-motivational-relational theory of emotion. American Psychologist, 46(8), 819.

Leung, K., Bond, M. H., de Carrasquel, S. R., Muñoz, C., Hernández, M., Murakami, F., Singelis, T. M. (2002). Social axioms: The search for universal dimensions of general beliefs about how the world functions. Journal of Cross-Cultural Psychology, 33(3), 286-302.

Leung, K., Ip, O. K., \& Leung, K. K. (2010). Social cynicism and job satisfaction: A longitudinal analysis. Applied Psychology, 59(2), 318-338.

Li, S., \& Chen, Y. (2018). The relationship between psychological contract breach and 
employees' counterproductive work behaviors: the mediating effect of organizational cynicism and work alienation. Frontiers in psychology, 9, 1273.

Luthans, F. (2002). The need for and meaning of positive organizational behavior. Journal of Organizational Behavior: The International Journal of Industrial, Occupational and Organizational Psychology and Behavior, 23(6), 695-706.

Luthans, F., Avey, J. B., Avolio, B. J., \& Peterson, S. J. (2010). The development and resulting performance impact of positive psychological capital. Human resource development quarterly, 21(1), 41-67.

Luthar, S. S., Cicchetti, D., \& Becker, B. (2000). The construct of resilience: A critical evaluation and guidelines for future work. Child development, 71(3), 543-562.

Mackey, J. D., Frieder, R. E., Brees, J. R., \& Martinko, M. J. (2017). Abusive supervision: A meta-analysis and empirical review. Journal of management, 43(6), 1940 1965.

Marcus-Newhall, A., Pedersen, W. C., Carlson, M., \& Miller, N. (2000). Displaced aggression is alive and well: a meta-analytic review. Journal of personality and social psychology, 78(4), 670.

Margolis, J. D., \& Walsh, J. P. (2003). Misery loves companies: Rethinking social initiatives by business. Administrative science quarterly, 48(2), 268-305.

Mayer, D. M., Kuenzi, M., Greenbaum, R., Bardes, M., \& Salvador, R. B. (2009). How low does ethical leadership flow? Test of a trickle-down model. Organizational behavior and human decision processes, 108(1), 1-13.

Mayer, D. M., Kuenzi, M., \& Greenbaum, R. L. (2010). Examining the link between ethical leadership and employee misconduct: The mediating role of ethical climate. Journal of Business Ethics, 95(1), 7-16.

Meyer, J. W., \& Jepperson, R. L. (2000). The 'actors' of modern society: The cultural construction of social agency. Sociological theory, 18(1), 100-120.

Meyer, J. W., \& Rowan, B. J. A. j. o. s. (1977). Institutionalized organizations: Formal structure as myth and ceremony. 83(2), 340-363.

Mikalef, P., Boura, M., Lekakos, G., \& Krogstie, J. (2019). Big data analytics and firm performance: Findings from a mixed-method approach. Journal of Business Research, 98, 261-276.

Miller, N., Pedersen, W. C., Earleywine, M., \& Pollock, V. E. (2003). A theoretical model of triggered displaced aggression. Personality and social psychology review, 7(1), 75-97.

Miller, N. E. (1941). I. The frustration-aggression hypothesis. Psychological review, 48(4), 337.

Mitchell, M. S., \& Ambrose, M. L. (2007). Abusive supervision and workplace deviance and the moderating effects of negative reciprocity beliefs. Journal of Applied Psychology, 92(4), 1159.

Moghaddam, A., \& Mahmoudi, M. M. (2018). The effect of organizational cynicism on tendency to deviant behaviours; the moderating role of leadership style

Molina, A. D. (2018). A systems approach to managing organizational integrity risks: Lessons from the 2014 veterans' affairs waitlist scandal. The American Review of Public Administration, 48(8), 872-885.

Mulki, J. P., Jaramillo, J. F., \& Locander, W. B. (2008). Effect of ethical climate on turnover intention: Linking attitudinal-and stress theory. Journal of business ethics, 78(4), 559-574.

Mulla, Z. R., \& Krishnan, V. R. (2014). Karma-yoga: The Indian model of moral development. Journal of Business Ethics, 123(2), 339-351. 
Nadim, M., Fatima, S., Aroos, S., \& Hafeez, M. H. (2019). Breach of Psychological Contract and Job Involvement: Does Organizational Cynicism Mediates the Relationship. Journal of managerial sciences, 13(3).

Nakamura, J., \& Csikszentmihalyi, M. (2014). The concept of flow. In Flow and the foundations of positive psychology (pp. 239-263): Springer.

Naseer, S., Raja, U., Syed, F., Donia, M. B., \& Darr, W. (2016). Perils of being close to a bad leader in a bad environment: Exploring the combined effects of despotic leadership, leader member exchange, and perceived organizational politics on behaviors. The Leadership Quarterly, 27(1), 14-33.

Naus, A. J. A. M. (2007). Organizational cynicism: on the nature, antecedents, and consequences of employee cynicism toward the employing organization. Maastricht University,

Naus, F., Van Iterson, A., \& Roe, R. (2007). Organizational cynicism: Extending the exit, voice, loyalty, and neglect model of employees' responses to adverse conditions in the workplace. Human relations, 60(5), 683-718.

Naus, F., van Iterson, A., \& Roe, R. A. (2007). Value incongruence, job autonomy, and organization-based self-esteem: $A$ self-based perspective on organizational cynicism. European Journal of Work and Organizational Psychology, 16(2), 195 219.

Neves, P. (2012). Organizational cynicism: Spillover effects on supervisor-subordinate relationships and performance. The Leadership Quarterly, 23(5), 965-976.

Newman, A., Round, H., Bhattacharya, S., \& Roy, A. (2017). Ethical climates in organizations: A review and research agenda. Business Ethics Quarterly, 27(4), 475-512.

Ng, T. W., Yam, K. C., \& Aguinis, H. (2019). Employee perceptions of corporate social responsibility: Effects on pride, embeddedness, and turnover. Personnel Psychology, 72(1), 107-137.

O'Connor, E. P., \& Crowley-Henry, M. J. J. o. B. E. (2019). Exploring the relationship between exclusive talent management, perceived organizational justice and employee engagement: Bridging the literature. 156(4), 903-917.

Pandey, A., Chandwani, R., \& Navare, A. (2018). How can mindfulness enhance moral reasoning? An examination using business school students. Business Ethics: $A$ European Review, 27(1), 56-71.

Park, H., Hoobler, J. M., Wu, J., Liden, R. C., Hu, J., \& Wilson, M. S. (2019). Abusive supervision and employee deviance: A multifoci justice perspective. Journal of Business Ethics, 158(4), 1113-1131.

Peng, H., \& Wei. (2018). Trickle-down effects of perceived leader integrity on employee creativity: A moderated mediation model. Journal of Business Ethics, 150(3), 837-851.

Pfrombeck, J., Doden, W., Grote, G., \& Feierabend, A. (2020). A study of organizational cynicism and how it is affected by social exchange relationships at work. Journal of Occupational Organizational Psychology.

Posner, B., \& Kouzes, J. (1993). Credibility: San Francisco: Jossey Bass.

Powell, T. C. (2019). Can quantitative research solve social problems? Pragmatism and the ethics of social research. Journal of Business Ethics, 1-8.

Reichers, A. E., Wanous, J. P., \& Austin, J. T. (1997). Understanding and managing cynicism about organizational change. Academy of management perspectives, 11(1), 48-59.

Rice, D. B., Taylor, R., \& Forrester, J. K. (2020). The unwelcoming experience of abusive 
supervision and the impact of leader characteristics: turning employees into poor organizational citizens and future quitters. European Journal of Work Organizational Psychology, 1-18.

Rizvi, S. T. H. (2016). The Effect of Psychological Capital on Employees' Voice and Loyalty Responses to Organizational Injustice-A two Dimensional Approach. Journal of managerial sciences, 1, 152.

Robinson, S. L., \& Bennett, R. J. (1995). A typology of deviant workplace behaviors: $A$ multidimensional scaling study. Academy of management Journal, 38(2), 555572.

Ryan, R. M., \& Deci, E. L. (2000a). Intrinsic and extrinsic motivations: Classic definitions and new directions. Contemporary educational psychology, 25(1), 54-67.

Ryan, R. M., \& Deci, E. L. (2000b). Self-determination theory and the facilitation of intrinsic motivation, social development, and well-being. American Psychologist, 55(1), 68.

Sager, K. L. (2008). An exploratory study of the relationships between theory $X / Y$ assumptions and superior communicator style. Management Communication Quarterly, 22(2), 288-312.

Sharma, D. (2018). When fairness is not enough: Impact of corporate ethical values on organizational citizenship behaviors and worker alienation. Journal of Business Ethics, 150(1), 57-68.

Sharma, P. N. (2018). Moving beyond the employee: The role of the organizational context in leader workplace aggression. The Leadership Quarterly, 29(1), 203217.

Simha, A., \& Cullen, J. B. (2012). Ethical climates and their effects on organizational outcomes: Implications from the past and prophecies for the future. Academy of management perspectives, 26(4), 20-34.

Simons, T. (2002). Behavioral integrity: The perceived alignment between managers' words and deeds as a research focus. Organization Science, 13(1), 18-35.

Sweetin, V. H., Knowles, L. L., Summey, J. H., \& McQueen, K. S. (2013). Willingness-topunish the corporate brand for corporate social irresponsibility. Journal of Business Research, 66(10), 1822-1830.

Tebes, J. K., Irish, J. T., Puglisi Vasquez, M. J., \& Perkins, D. V. (2004). Cognitive transformation as a marker of resilience. Substance Use \& Misuse, 39(5), 769788.

Tepper, B. J. (2000). Consequences of abusive supervision. Academy of Management Journal, 43(2), 178-190.

Tepper, B. J., Duffy, M. K., Henle, C. A., \& Lambert, L. S. (2006). Procedural injustice, victim precipitation, and abusive supervision. Personnel Psychology, 59(1), 101123.

Tepper, B. J., Moss, S. E., \& Duffy, M. K. (2011). Predictors of abusive supervision: Supervisor perceptions of deep-level dissimilarity, relationship conflict, and subordinate performance. Academy of management Journal, 54(2), 279-294.

Tepper, B. J., Simon, L., \& Park, H. M. (2017). Abusive supervision. Annual Review of Organizational Psychology and Organizational Behavior, 4, 123-152.

Tong, J., Chong, S., Chen, J., Johnson, R. E., \& Ren, X. (2020). The Interplay of Low Identification, Psychological Detachment, and Cynicism for Predicting Counterproductive Work Behaviour. Applied Psychology, 69(1), 59-92.

Tugade, M. M., \& Fredrickson, B. L. (2004). Resilient individuals use positive emotions to bounce back from negative emotional experiences. Journal of personality and 
social psychology., 86(2), 320.

Tugade, M. M., \& Fredrickson, B. L. (2007). Regulation of positive emotions: Emotion regulation strategies that promote resilience. Journal of happiness studies, 8(3), 311-333.

Vansteenkiste, M., \& Ryan, R. M. (2013). On psychological growth and vulnerability: basic psychological need satisfaction and need frustration as a unifying principle. Journal of psychotherapy integration, 23(3), 263.

Wagner, T., Korschun, D., \& Troebs, C.-C. (2019). Deconstructing corporate hypocrisy: A delineation of its behavioral, moral, and attributional facets. Journal of Business Research.

Wagner, T., Lutz, R. J., \& Weitz, B. A. (2009). Corporate hypocrisy: Overcoming the threat of inconsistent corporate social responsibility perceptions. Journal of Marketing, 73(6), 77-91.

Walumbwa, F. O., Hartnell, C. A., \& Misati, E. (2017). Does ethical leadership enhance group learning behavior? Examining the mediating influence of group ethical conduct, justice climate, and peer justice. Journal of Business Research, 72, 1423.

Wang, M., Sinclair, R., \& Deese, M. N. (2010). Understanding the causes of destructive leadership behavior: A dual-process model.

White, R. W. (1959). Motivation reconsidered: The concept of competence. Psychological review, 66(5), 297.

Wimbush, J. C., \& Dalton, D. R. (1997). Base rate for employee theft: Convergence of multiple methods. Journal of Applied Psychology, 82(5), 756.

Wimbush, J. C., \& Shepard, J. M. (1994). Toward an understanding of ethical climate: Its relationship to ethical behavior and supervisory influence. Journal of Business Ethics, 13(8), 637-647.

Wurthmann, K. (2020). How group and perceiver characteristics affect collective blame following counterproductive work behavior. Journal of Business Ethics: A European Review, 29(1), 212-226.

Xu, E., Huang, X., Jia, R., Xu, J., Liu, W., Graham, L., \& Snape, E. (2020). The "Evil Pleasure": Abusive Supervision and Third-Party Observers' Malicious Reactions Toward Victims. Organization Science.

Xu, S., Martinez, L. R., Van Hoof, H., Tews, M., Torres, L., \& Farfan, K. (2018). The impact of abusive supervision and co-worker support on hospitality and tourism student employees' turnover intentions in Ecuador. Current issues in Tourism, 21(7), 775-790.

Yang, L., Manika, D., \& Athanasopoulou, A. (2019). Are they sinners or saints? A multilevel investigation of hypocrisy in organisational and employee pro-environmental behaviours. Journal of Business Research.

Yurtkoru, E. S., Ensari, S., \& ErdilekKarabay, M. (2018). To what extent trust in leader and ethical climate affect turnover intention? A research on private and public bank employees. Industrial Management -Chicago then Atlanta, 12-26.

Zacher, H., Pearce, L. K., Rooney, D., \& McKenna, B. (2014). Leaders' personal wisdom and leader-member exchange quality: The role of individualized consideration. Journal of Business Ethics, 121(2), 171-187.

Zechmeister, E. B., \& Posavac, E. J. (2003). Data analysis and interpretation in the behavioral sciences: Wadsworth Pub Co.

Zellars, K. L., Tepper, B. J., \& Duffy, M. K. (2002). Abusive supervision and subordinates' organizational citizenship behavior. Journal of Applied Psychology, 87(6), 1068. 
Zhang, Y., \& Bednall, T. C. (2016). Antecedents of abusive supervision: A meta-analytic review. Journal of Business Ethics, 139(3), 455-471.

Zhao, M., Chen, Z., Glambek, M., \& Einarsen, S. V. (2019). Leadership Ostracism Behaviors from the target's perspective: A content and behavioral typology model derived from interviews with Chinese employees. Frontiers in psychology, 10.

Zona, F., Minoja, M., \& Coda, V. (2013). Antecedents of corporate scandals: CEOs' personal traits, stakeholders' cohesion, managerial fraud, and imbalanced corporate strategy. Journal of Business Ethics, 113(2), 265-283. 